\title{
Polysaccharides of higher fungi: biological role, structure and antioxidative activity
}

\author{
Maja S. Kozarski ${ }^{1}$, Anita S. Klaus ${ }^{1}$, Miomir P. Nikšić ${ }^{1}$, Leo J. L. D. Van Griensven ${ }^{2}$, Miroslav M. Vrvić ${ }^{3,4}$, \\ Dragica M. Jakovljević ${ }^{4}$ \\ ${ }^{1}$ University of Belgrade, Faculty of Agriculture, Belgrade, Serbia \\ ${ }^{2}$ Plant Research International, Wageningen University and Research, Wageningen, The Netherlands \\ ${ }^{3}$ University of Belgrade, Faculty of Chemistry, Belgrade, Serbia \\ ${ }^{4}$ University of Belgrade, Institute of Chemistry, Technology and Metallurgy, Belgrade, Serbia
}

\begin{abstract}
The fungal polysaccharides attract a lot of attention due to their multiple challenging biological properties, such as: anti-tumor, anti-viral, anticomplementary, anticoagulant, hypolipidemic, immunomodulatory and immune-stimulatory activities, which all together make them suitable for application in many quite distinctive areas, such as food industry, biomedicine, cosmetology, agriculture, environmental protection and waste water management. This article presents results with respect to biological properties, structure and procedures related to the isolation and activation of polysaccharides of higher fungi. It is considered and presented along with a review of the critical antioxidative activity and possible influence of the structural composition of polysaccharide extracts (isolated from these higher fungi) upon their antioxidative properties.
\end{abstract}

Keywords: polysaccharides, fungi, polysaccharide extracts, antioxidative properties.

REVIEW PAPER

UDC 582.28:635.8:547.458:615.279

Hem. Ind. 68 (3) 305-320 (2014)

doi: 10.2298/HEMIND121114056K

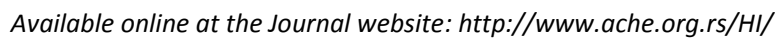

The mycotherapy became acknowledged in the past 50 years as a new approach to the treatment in contemporary medicine and immunology. A wide spectrum of strong medicinal effects of fungi comes from some of their components. Fungi contain numerous biologically active compounds, such as various polysaccharides ( $\beta$-glucans, chitin and heteropolysaccharides), terpenes, phenols, essential amino acids, lectins, nucleotides, sterols and unsaturated fatty acids. Besides, they also contain many minerals and vitamins. The active components of fungi are today known for their anti-inflammatory and anti-tumor properties, prevention of cardiovascular diseases, antiparasitic, heaptoprotective and anti-diabetic, antimicrobial and antioxidative properties [1-4]. The active substances of fungi affect the maintenance of biological homeostasis and re-establishment of the balance and natural defence system of the organism. Nowadays, in the medicine and pharmacology of the Far East, numerous preparations made from medicinal fungi with antitumor and immunomodulating properties are produced in the form of capsules, ampoules, extracts and teas. The Japan lentinan, a polysaccharide obtained from the mushroom Lentinula edodes and krestin (PSK) obtained from the mushroom Coriolus versicolor, has

Correspondence: D.M. Jakovljević, Institute of Chemistry, Technology and Metallurgy, University of Belgrade, Njegoševa 12, 11001 Belgrade, P.O. Box 473, Serbia

E-mail: djakovlj@chem.bg.ac.rs

Paper received: 14 November, 2012

Paper accepted: 5 June, 2013 been registered as anti-cancer drug since mid-1980s and it is among the first 10 anti-tumor preparations in that market [5]. Therefore, nowadays, fungi are considered to be functional food and a source of physiologically important components.

\section{HIGHER FUNGI AS A SOURCE OF BIOLOGICALLY ACTIVE POLYSACCHARIDES}

Polysaccharides of higher fungi are used as adaptogens and immunostimulators. The immunostimulatory effect of polysaccharides is prophylactic and it belongs to a non-invasive form of treatment, for instance the prevention of infectious disease and of tumor metastases. These molecules do not directly attack pathogens related to the cancer cells. They achieve their anti-tumor effect indirectly, through activation of various defensive immune responses [6-10].

The immunomodulating properties of polysaccharides of higher fungi include mitogenic activity, stimulation of the pluripotent stem cell in the process of hematopoiesis, activation of the alternative complement pathway and activation of the immune system cells such as macrophages, $T$ helper cells (Th cells) and cytotoxic T cells (Tc cells), natural killer cells (NK cells) and $B$ cells [15]. Recent investigations have shown that the receptors, such as the Complement Receptor Type 3 (CR 3, $\alpha_{\mathrm{M}} \beta_{2}$ integrin or CD11b/CD 18) on phagocytes and NK cells and the Toll-like receptor group, i.e. TLR-2 and TLR-4, as well as Dectin-1 on the macrophage surface, are the main receptors that are specifically 
recognized and bound by polysaccharide molecules [11-14]. Interactions among them further stimulate the cascade of the immune response including the production of cytokines such as interleukin- $1 \beta$ (IL-1 $\beta$ ), interleukin-2 (IL-2), interleukin-6 (IL-6), interleukin-10 (IL-10) and interferon- $\gamma$ (INF- $\gamma$ ) and the tumor necrosis factor- $\alpha$ (TNF- $\alpha$ ) [15]. Polysaccharides of higher fungi have effects on the maturation, differentiation and proliferation of the immune system cells through the network of the spectrum of interleukines and interferons, Figure 1.

More than 650 types of medicinal fungi are known today. Besides the immunostimulatory and anti-tumor effects, their polysaccharides have additional beneficial effects such as the suppression of damages caused by cytostatics and radiation to the immune system cells [16-18].

Polysaccharides isolated from various types of fungi may significantly affect the support of the immune system of an organism in its fight against infectious disease such as parainfluenza viruses and rhinoviruses, herpes simplex and herpes zoster viruses, cytomegalovirus, Epstein-Barr virus, hepatitis viruses $[19,20]$. Lentinan obtained from the mushroom Lentinula edodes in combination with azidothymidine (AZT) reduces the expression of human immunodeficiency virus (HIV) on the surface of $T$ cells to a significantly higher extent than only AZT application [4,21]. According to the medical protocols, all strategies applied in the treatment of acquired immunodeficiency syndrome (AIDS) are based on the activation of the immune system of the body, thus creating the most effective immunological response. Besides that, $\beta$-glucans of fungi are used today effectively in the treatment of dermatitis, such as bacterial foot infections in athletes [22].

The majority of active fungal polysaccharides, soluble or unsoluble in water, may be classified as dietetic fibres ( $\beta$-glucans, chitin, various heteropolysaccharides). Fungal dietetic fibres protect the colon mucous membrane from detrimental effect of certain substances, and at the same time they serve as a good basis (prebiotics) for the stimulation of growth of beneficial bacteria (probiotics) that have already been present in the gastrointestinal tract and that prevent, through mutual interaction, the development and occurence of diabetes, atherosclerosis, hypertension and trombosis. Nowadays, preparations based on dietary fibres isolated from various types of fungi have a worldwide commercial value of USD 5-6 billion a year $[4,22,23]$

Globally, the number of newly registered patents based on polysaccharides of higher fungi has been increasing. The schizophyllan, curdlan, lentinan and scleroglucan have been used as nucleic acid-binding agents since 2003 . The obtained complexes of polysaccharides (glucans) and nucleic acids are used as gene

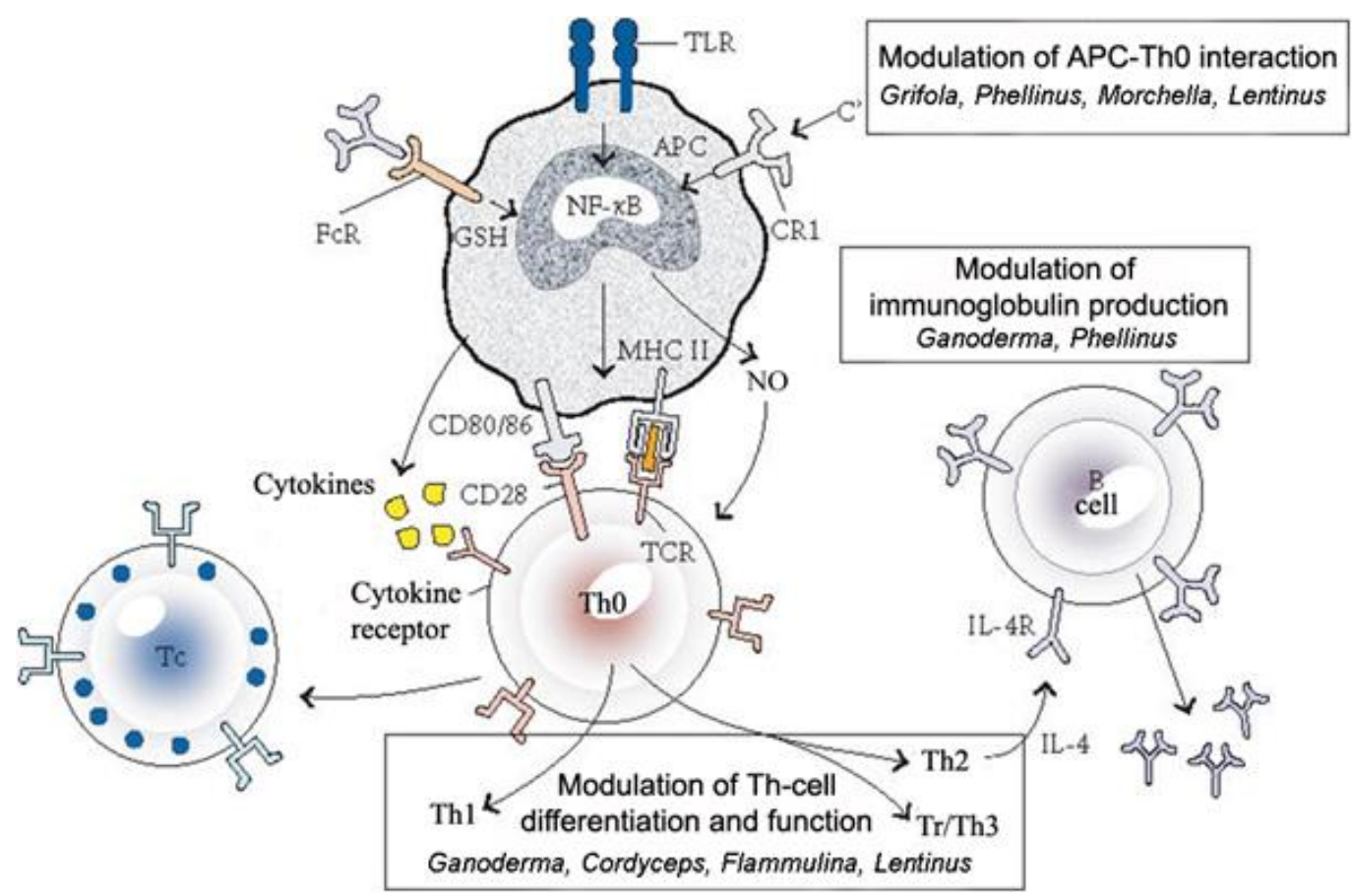

Figure 1. Schematic representation of the possible targets of the adaptive immune system for mushroom ingredients with immunomodulatory properties. APC: antigen-presenting cell; FCR: FC receptor; TLR: Toll-like receptor; CR1: complement receptor type 1; C': activated complement; GSH: glutathione; MHC II: major histocompatibility complex class II; TCR: T-cell receptor; Th: helper T cells; Tc: cytotoxic T cells; Tr: regulatory T cells; NO: nitric oxide; IL-4: interleukin-4; IL-4R: interleukin-4 receptor; $C D$ : cluster designation [15]. (Figure reprinted with permission from Hindawi Publishing Corporation). 
therapy vectors, for the treatment of genetic diseases. Such complexes exhibit resilience to nucleases and serve as the protective structures of nucleic acids [22].

$\beta$-Glucans of higher fungi are used in cosmetology, in protective creams that prevent irritation and diseases of the skin. They are also used to protect the skin from ultraviolet radiation [22].

\section{Structure of biologically active polysaccharides}

About 650 types and 7 interspecific taxa from 182 genera of higher hetero- and homobasidiomycetes are known today, they contain pharmacologically active polysaccharides which may be isolated from the carpophore, mycelium or cultivation media $[4,24]$.

$\beta$-D-glucans together with molecules of chitin, celluloses and glycoproteins form the fungal cell wall $[23,24]$.

Lentinan from the mushroom Lentinula edodes has been the most studied fungal glucan, Figure 2 . The
Also, some other sugar molecules may be bound to molecules of $\beta$-D-glucan, such as mannose, xylose, galactose or uronic acids, and also peptides and protein molecules [24]. The investigation of their structure has confirmed that these macromolecules have a triple helical conformation, Figure $3[28,29]$.

The biomodulating activity of various myco-D-glucans is depending on their chemical properties, such as molecular weight, branching level, solubility in water and tertiary structure. Research efforts focused on the structural identification of biologically active polysaccharides of higher fungi are hot topics today [31,32].

\section{Isolation of polysaccharides}

The extraction procedure and the method used for the purification of the obtained fractions of active polysaccharides depend in many aspects on the type of a fungus and physical properties of polysaccharides, such as solubility, molecule conformation, branching

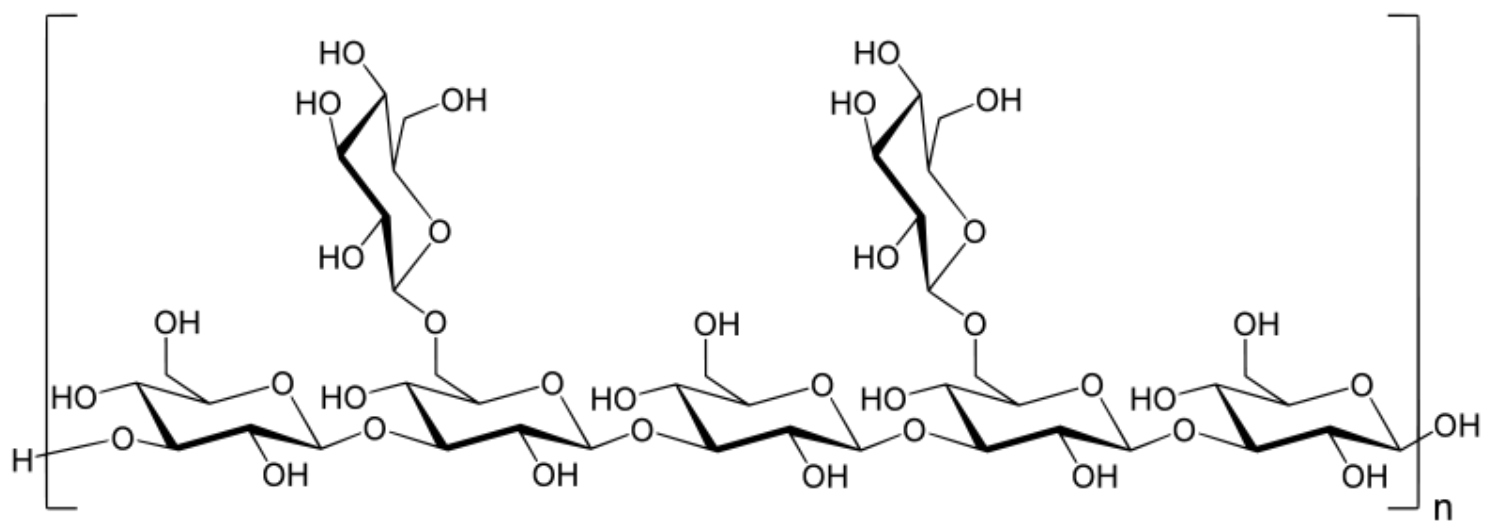

Figure 2. Chemical structure of lentinan [27]

basis of this molecule comprises the main chain made of glucose molecules connected by $\beta$-(1 $\rightarrow 3)$-glycosidic linkage. One part of the glucose units from the main chain is substituted via the position of $0-6$, with side chains that are linked by $\beta-(1 \rightarrow 6)$-glycosidic linkage. The molecular weight of lentinan approximately amounts to $500 \mathrm{kDa}$, the branching level is $0.40(2 / 5)^{*}$, and solved in water it makes a triple helical conformation $[25,26]$. Among the immunomodulatory polysaccharides, which role and structure have been studied in detail, are grifolan, obtained from the fungus Grifola frondosa, schizophyllan, obtained from the fungi Schizophyllum commune, Sclerotonia sclerotiorum glucan (SSG), PSK and the polysaccharide-peptide complex (PSP), obtained from the fungus Coriolus versicolor.

\footnotetext{
*The branching level is the number $\beta-(1 \rightarrow 6)$-glycosidic linkages of the side chain divided by the number $\beta-(1 \rightarrow 3)$-glycosidic linkages of the main chain.
}

level, molecular weight. The selection of extraction methods depends on the biosynthesis site and the activity in the cell, transportation and their biological function. This is why non-polar organic solvents are used, for example, for substances that exhibit their activity in the inner part of the cell. However, the aqueous solutions are used for substances that exhibit their activity on the cell surface [33].

After two decades of intensive investigations related to the medicinal fungi, reliable procedures for effective extraction, fractioning and purification of polysaccharides from the carpophore or mycelium have been devised. In general, this scheme includes the extraction of polar compounds with the use of $80 \%$ ethanol, after which three successive extractions were applied, with water $\left(100{ }^{\circ} \mathrm{C}, 3 \mathrm{~h}\right), 2 \%$ ammonium oxalate $\left(100{ }^{\circ} \mathrm{C}, 6 \mathrm{~h}\right)$ and $5 \%$ sodium hydroxide $\left(80^{\circ} \mathrm{C}, 6 \mathrm{~h}\right)$ [5]. The first extraction results in a polysaccharide fraction that is dissolved in water, while the other two 
fractions of polysaccharides are water-insoluble. Extracted polysaccharides may further be purified through the combination of various methods, such as fraction precipitation by ethanol in various concentrations, precipitation performed by acetic acid, ion exchange chromatography, affinity chromatography, gel filtration [24].

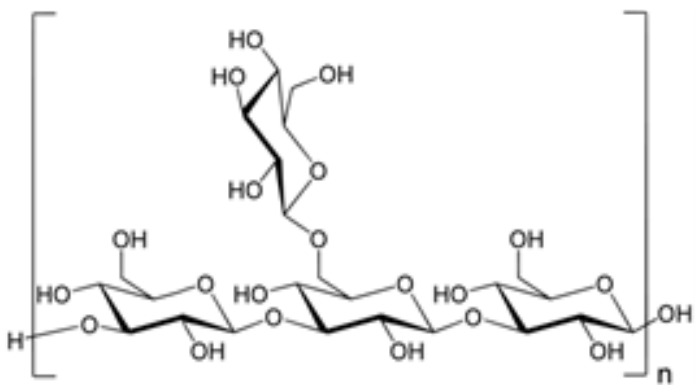

(a)

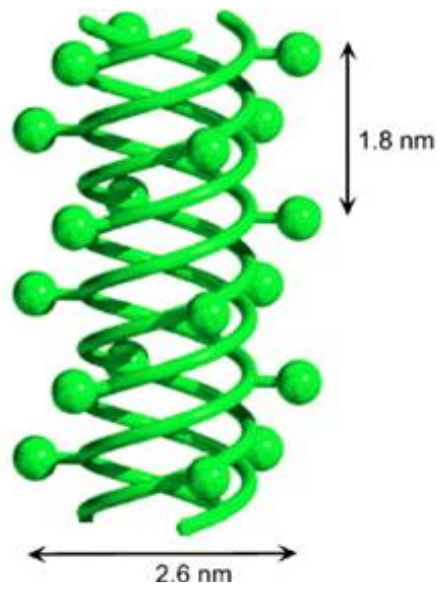

(b)

Figure 3. Repeating unit of schizophyllan (a); a representative model of the triple helix (b) [30]. (Figure reprinted with permission from Elsevier).

Through hot water extraction of the basidiomycete Lentinula edodes the polysaccharide lentinan was obtained, which was then followed by precipitation in $70 \%$ ethanol and lyophilization of the precipitate. Repeated precipitation in alcohol led to a polysaccharide extraction of $87.5 \%$ purity [34].

\section{Activation of polysaccharides by chemical modification}

Modified biologically active polysaccharides have significant application due to their improved properties, such as, for example, the increase in solubility in aqueous solvents [35]. There are various methods of chemical modification of fungal polysaccharides that yield the best defined products for further use. The two basic procedures by which modified polysaccharides of fungi can be obtained for clinical application are: a) the modification by Smith degradation and b) activation with the formolysis method. These procedures are the most successfully developed for the polysaccharides from the fungi Ganoderma lucidum, Grifola frondosa and Leucopaxillus giganteus (= Triholoma gigantea). Carboxymethylation is an additional chemical method that results in derivates of water soluble $\beta$-glucans, as opposed to the initial native polymers [24].

Enzymatic modification by cellulases, amylases and proteases is used to obtain modified biologically active glucans with a lower molecular mass [36,37]. Acetylated linear $\alpha$-(1 $1 \rightarrow 4)$-glucan which has a molecular mass of about $5 \mathrm{kDa}$, was obtained by enzymatic reduction of side chains from active hexose correlated compound (AHCC) and it is considered to be main active ingredient. AHCC is a product prepared by cultivation and enzymatic modification of several species of mushroom mycelia, including shiitake, grown in rice bran extract as the primary food source and contains a mixture of polysaccharides ( $74 \%$ of AHCC from where $\sim 20 \%$ being of the $\alpha$-1,4-glucan type), proteins, lipids and minerals [38].

\section{OXIDATIVE STRESS, FREE RADICALS, ANTIOXIDANTS}

Free radicals (FRs) are involved in pathological processes (diabetes mellitus, HIV infection, autoimmune, neurodegenerative, coronary, malignant, pulmonary, inflammatory and many other diseases) and they are part of the complex pathophysiological mechanisms of cell damage [39-41]. When the chain of FRs reactions is started, they tend to spread in space and time, with an increasing effect. This propagation is reflected in the occurance of secondary FRs that continue to spread to a cascade of chain reactions [41].

The mechanisms by which these pathologies develop involve generally oxidative alteration of physiologically critical molecules, including proteins, lipids, carbohydrates and nucleic acids, along with modulation of gene expression and the inflammatory response.

The human organism has developed defense systems to deal with this oxidative stress. These include expression of enzymatic systems, via activation of Nuclear Factor Kappa B (NF-кB) transcription factors, especially superoxide dismutases, catalases, gluthation peroxidases and thioredoxin systems, which are recognized as being highly efficient in reactive oxygen species (ROS) detoxification. The main nonenzymatic antioxidants present in the human organism are gluthation, bilirubin, estrogenic sex hormones, uric acid, coenzyme $Q$, melanin, melatonin, $\alpha$-tocopherol and lipoic acid $[42,43,46]$.

NF- $\kappa B$ also plays a central role in the processes of inflammation and immunity. While certain NF-KB-regulated genes play a major role in regulating the amount of ROS in the cell, ROS has various inhibitory or stimulatory roles in NF-KB signaling. In such a way, ROS can 
directly interact with the components of the NF-KB pathway leading to its up- or down-regulation. In spite of this, the appearance of ROS in the nucleus might exclusively lead to the reduction of NF-KB binding to DNA, which may also cause inflammation processes and pathological conditions [43-45].

Oxidative degeneration of fats and oils in food has an significant impact on the quality and safety of food due to the occurrence of secondary, potentially toxic compounds. The addition of antioxidants is necessary to preserve the colour and taste of nutritious products, and to avoid vitamin degradation [46]. Antioxidants are not only used in the food industry, but also in cosmetology and in the pharmaceutical industry, as well as in the manufacturing of tyres and fuels (gas and biodiesel), in order to prevent oxidative degradation processes.

Natural antioxidants, such as vitamins (A, E and C), minerals (Se and $\mathrm{Zn}$ ), proteins (transferrine, ceruloplasmin, albumin), glutathione and polyphenols and flavonoids possess the property of catching free radicals, thus inhibiting oxidative mechanisms that lead to degenerative diseases [41]. Synthetic antioxidants, such as butylated hydroxyanisole (BHA), butylated hydroxytoluene (BHT), propyl gallate (PG) and tertiary butylhydroquinone (TBHQ) are largely applied in food industry, where they are used as natural supplements to antioxidants for the purpose of improvement of their efficacy. However, despite their high efficacy in the process of catching free radicals, there are indications that some of synthetic antioxidants exhibit adverse, toxic effects $[47,48]$. Therefore, increased attention is paid to investigations of new natural sources of antioxidants. These investigations are focused on the decrease of the production costs and on the improvement of solubility of such substances in emulsions used in the food industry. Some of well-known natural sources of antioxidants are isolated from spices such as oregano, thyme, dictamon, marjoram, lavander and rosemary, but have limited application due to their strong and specific taste. Additive industry had a turnover of USD 3.7 billion at the US market in the year 2007, based on antioxidants, with the tendency of further growth by about $3 \%$ per annum $[49,50]$.

Today, the broader impact of proper nutrition on human health becomes increasingly important. Both investigations and clinical studies indicate that nutrition rich in foodstuffs of plant origin, such as fruits, vegetables, grains, sprouts, and the consumption of teas, red wine and juices ensures the reduction of risks of development of human disease [51], including cancer and cardiovascular diseases that are the leading cause of death in the modern world. Most antioxidative components in the typical nutrition comprising foodstuffs of plant origin belong to various classes of phenolic compounds. Phenolic acids, polyphenols and flavonoids in fruits and vegetables are classified into the group of non-essential dietary components. The bioactivity of phenols may be associated with their property to chelate metals, inhibit lipoxygenases and catch free radicals, because of which they are considered as basic components that have a favourable effect on health [52-55]. Some authors have pointed out that the antioxidating effect of foodstuffs of plant origin is in correlation with the content of complexes made by phenolic compounds with lignins and arabinoxylans. Such complexes isolated from barley and malt have shown twice higher antioxidative activity than the extract of free phenolic compounds from the same material $[56,57]$. Other authors believe that the antioxidative activity is not directly connected with free or bound phenolic compounds [58].

\section{DETERMINATION OF ANTIOXIDANT ACTIVITY}

The various methods are used in order to measure antioxidative properties that are appropriate for various levels of antioxidative activity, such as methods based on the transfer of electrons and hydrogen atom [59], the ability to chelate ferrous $\left(\mathrm{Fe}^{2+}\right)$ ions, the method of electron spin resonance (ESR), erythrocyte hemolysis, and the monitoring of the activity of superoxide dismutase (SOD), catalase (CAT) and glutathione peroxidase (GPX), Table 1.

During the determination of antioxidative properties of the tested samples, which are primarily foodstuffs, one should take into consideration the fact that the total antioxidative capacity results from a combined activity of various antioxidants that are present in the tested material, their respective concentrations and possibilities for synergic or antagonistic reactions [46].

In order to determine antioxidative properties of the tested samples it is necessary to apply a number of different methods based on various reaction mechanisms. Some components may give completely different responses, depending on the applied method $[52,54,59,60]$.

Antioxidants can exercise their protective properties at different stages of the oxidation process and by different mechanisms. There are two main types of antioxidants, namely, primary (chain breaking, free radical scavengers) and secondary or preventive. Secondary antioxidant mechanisms may include deactivation of metals, inhibition of breakdown of lipid hydroperoxides to unwanted volatile products, regeneration of primary antioxidants, singlet oxygen quenching, etc. [61]. But also it should be kept in mind that antioxidants often act via mixed mechanisms that combine different types of antioxidation. 
Table 1. List of antioxidant methods [59,60]

\section{Name of the method}

Hydrogen Atom Transfer methods (HAT)

Oxygen radical absorbance capacity (ORAC)

Lipid peroxidation inhibition capacity (LPIC)

Total radical trapping antioxidant parameter (TRAP)

Inhibited oxygen uptake (IOC)

Crocin bleaching nitric oxide radical inhibition activity

Hydroxyl $\left(\mathrm{HO}^{\bullet}\right)$ radical scavenging activity by $p$-butrisidunethyl aniline (PNDA)

Scavenging of peroxide $\left(\mathrm{ROO}^{\bullet}\right)$ radicals

ABTS radical scavenging method

Scavenging of super oxide $\left(02^{\bullet-}\right)$ radical formation by alkaline (SASA)

Electron Transfer methods (ET)

Trolox equivalent antioxidant capacity (TEAC) decolourization

Ferric reducing antioxidant power (FRAP)

1,1-Diphenyl-2-picrylhydrazyl (DPPH) free radical scavenging assay

Cupric ion reducing antioxidant capacity (CUPRAC)

Total phenols by Folin-Ciocalteu

$\mathrm{N}, \mathrm{N}$-dimethyl-p-phenylenediamine (DMPD) assay

\section{Other Assays}

Total oxidant scavenging capacity (TOSC)

Inhibition of Briggs-Rauscher oscillation reaction

Chemiluminescence

Electrochemiluminescence

Fluorometric Analysis

Enhanced chemiluminescence (ECL)

TLC bioautography

Cellular antioxidant activity (CAA) assay

Dye-substrate oxidation method

Besides the mechanism of antioxidants effects, it is extremely important to understand the antioxidant and pro-oxidant behavior of bioactive substances according to their structure, chemical environment and the experimental conditions involved. For example, gallic acid and epigallocatechin gallate, antioxidative tea components, exhibit high antioxidative activity, but they may also act as pro-oxidants [62,63]. Moreover it is now well established that flavonoids can have a pro -oxidant effect [64] in the presence of $\mathrm{Cu}^{2+}$. Also it is established that $\beta$-carotene behaves only as a radicaltrapping antioxidant, when the partial oxygen pressure is below $20 \mathrm{kPa}$ (normal ambient oxygen pressure). However, when the pressure increases, $\beta$-carotene loses its antioxidant activity and has an autocatalytic pro-oxidant effect which increases with its concentration $[46,65]$.

An important factor, when antioxidant efficacy of compounds is evaluated, is also medium polarity. Antioxidants behave differently in media with different polarities and phase states, e.g., antioxidants have been difficult to evaluate in oils and food emulsions due to the complex interfacial phenomena involved [66]. Many studies, concerning methods for measuring antioxidant activity in organic media, have shown that hydrogen bonding of solvents can induce a sharp change in the antioxidant capacity of phenol compounds and especially in their ability to shed an $\mathrm{H}$ atom [46]. Hydrogen bonding in the solvent also affects the antioxidant mechanism. Hence, quercetin does not function like chain-breaking antioxidant in tert-butyl alcohol, which is a protic medium, but rather as retarder, while it acts like chain breakers in chlorobenzene, which is an aprotic solvent [67].

Moreover, the natural antioxidants have been difficult to evaluate in oils and food emulsions in view of the complex interfacial affinities between involved airoil and oil-water interfaces and the questionable conditions and methodology used to follow oxidation [66]. This is clearly illustrated by Porter's polar paradox [68] in which polar antioxidants, e.g., Trolox, are more often active in lipid solutions than apolar antioxidants, e.g., $\alpha$-tocopherol, whereas apolar antioxidants are more efficient in emulsion media than their polar homologues. This paradox is based on the interface properties of antioxidants, on their partitioning in multiphase media [66] and on the fact that lipid oxidation is initiated at the system interfaces. 
Apart from the complexity of the entire process of determining the antioxidant activity of the various components, it must be kept in mind that in vitro assays can only rank antioxidant activity for their particular reaction system and that their relevance to in vivo health protective activities is uncertain. Therefore, it is prudent to use more than one type of antioxidant assay to measure antioxidant activities, and to include at least one assay that has biological relevance.

\section{ANTIOXIDATIVE PROPERTIES OF FUNGI}

Besides many plants, fungi are significant sources of antioxidative components. Some edible fungi, such as Agaricus bisporus, Grifola frondosa, Hericium erinaceus, Flammulina velutipes, Lentinula edodes, Pleurotus eryngii and Pleurotus ostreatus have the significant antioxidative activity and the ability to catch free radicals [69-72 ]. Such properties have also been proven in case of fungi that are important in medicine, such as Agaricus brasiliensis, Sparassis crispa, Phellinus linteus, Ganoderma lucidum and Inonotus obliquus [73-76]. It is generally accepted that extracts of fungi comprise many components and each of them has its own biological effect. The method of extraction, i.e., the type of the applied solvents for the extraction directly affects antioxidative properties of fungi $[73,77,78]$. It has been established that extracts from fungi that have been obtained by water extraction comprise various polysaccharides, phenolic compounds and proteins, including lectins $[74-77,79]$. Fungi also accumulate a range of various secondary metabolites, which include, besides phenols, polyketides, terpenes, flavonoids and steroids $[3,4]$.

\section{Antioxidative properties of polysaccharide extracts of higher fungi}

The antioxidative activity of polysaccharides is attributed to their ability to scavenge free radicals, their reduction property and ability to chelate $\mathrm{Fe}^{2+}$, lipid peroxidation inhibition, erythrocyte hemolysis and the increase of activities in eukaryotic as well as in prokaryotic cells of enzymes that take part in antioxidative processes, such as SOD, CAT and GPx [80-84]. In some researches, besides the increase in the enzyme activity, antioxidative properties are also attributed to the property of polysaccharides to induce an increased expression of antioxidative enzymes, such as SOD and GPx [85].

Polysaccharide extracts of higher fungi with antioxidative properties are most frequently obtained through the extraction procedures that involve hot water and alcohol precipitation, and alkaline extraction [75$-77,80,86]$. The concentration of polysaccharides, as bioactive compounds, depends a lot on the stage of development of the fruiting bodies, time period that has elapsed from the moment of picking until the commencement of the investigation, storage conditions and the additional purification of extracts [77,87-90]. The total content of glucans in relation to the total content of polysaccharides varies, depending on the type of the fungus and the applied extraction procedure. It has been established that glucans in extracts primarily possess $\beta$-glycosidic linkages. Polysaccharide extracts contain glucose, as the prevailing monosaccharide component, and to a smaller or greater extent some other sugars [75-77,79,86,90].

The ability to scavenge free radicals depends on the size of the carbohydrate molecule; polysaccharides have a greater ability of neutralizing free radicals than monosaccharides, but that antioxidative activity is still rather low. Polyelectrolytes, such as sulfated or phosphorylated glucans, lipopolysaccharides and surprisingly-mannans, exhibit significantly stronger free radicals scavenging ability $[84,91,92]$.

The ability to scavenge free radicals of polysaccharides molecules may be conditioned by the presence of hydrogen from specific, certain monosaccharide units, and the type of their binding in side branches of the main chain. This is how the direct connection between the monosaccharide composition, side chain conformation and ability to catch DPPH radicals of polysaccharides isolated from the filtrate that has been obtained by submerse cultivation of the fungus $L$. edodes has been determined. It has been detected that the presence of glucopyranose units that are linked by $\beta-(1,6)$-glycosidic linkages and arabinose bound by $(1,4)$-linkages in the side chains has a significant impact on the capacity of catching free radicals as compared to ascorbic acid, BHA and citric acid [84].

By measuring of $E C_{50}$ values when testing the antioxidative activity by the DPPH method of polysaccharide extracts, obtained by hot water extraction from the fruiting bodies of the fungus $P$. linteus, the commercial extract of spores of G. lucidum, and polysaccharide extracts of the fungi $G$. applanatum and $L$. edodes, additionally purified by dialysis (MWCO 8000-10000 Da), it has been observed that they are comparable with $E C_{50}$ values of the standard commercial antioxidants $\alpha$-tocopherol and ascorbic acid, Figure 4 . The values of $E C_{50}$ for polysaccharide extracts of fungi $S$. commune, A. brasiliensis, T. versicolor and G. lucidum are, according to this method, 15-120 times lower than the values of $E C_{50}$ for BHT. Starch and amylopectine have exhibited a very low ability of protoning DPPH radicals $[75,76,86,90]$. Being rapid, simple and independent of sample polarity, the DPPH method is very convenient for the quick screening of many samples for radical scavenging activity [93].

The polysaccharide extract isolated by water extraction from the fungus $G$. atrum has revealed a 
significantly higher efficacy in protoning free DPPH radicals than the chromatographically purified polysaccharide fractions of the same extract. In accordance with the obtained results, it has been concluded that other components that are present in the extract, such as proteins, peptides, amino acids, phytosterols, nucleotides, organic acids and microelements, as well as their potential interactions and synergic effects, can have a significant impact on the increase of antioxidant properties [79]
Polysaccharide extracts of higher fungi have been proven effective in the prevention of lipid peroxidation in the linoleic acid model system, Figure 4. Extracts with a higher share of non-polysaccharide, primarily phenolic components, are more effective in the protection of lipids from oxidative damages in vitro $[75,76,86]$.

By testing the level of inhibition of lipid peroxidation in the linoleic acid model system of polysaccharides isolated from the fungus $L$. edodes, a high correlation between the content of some monosaccharide

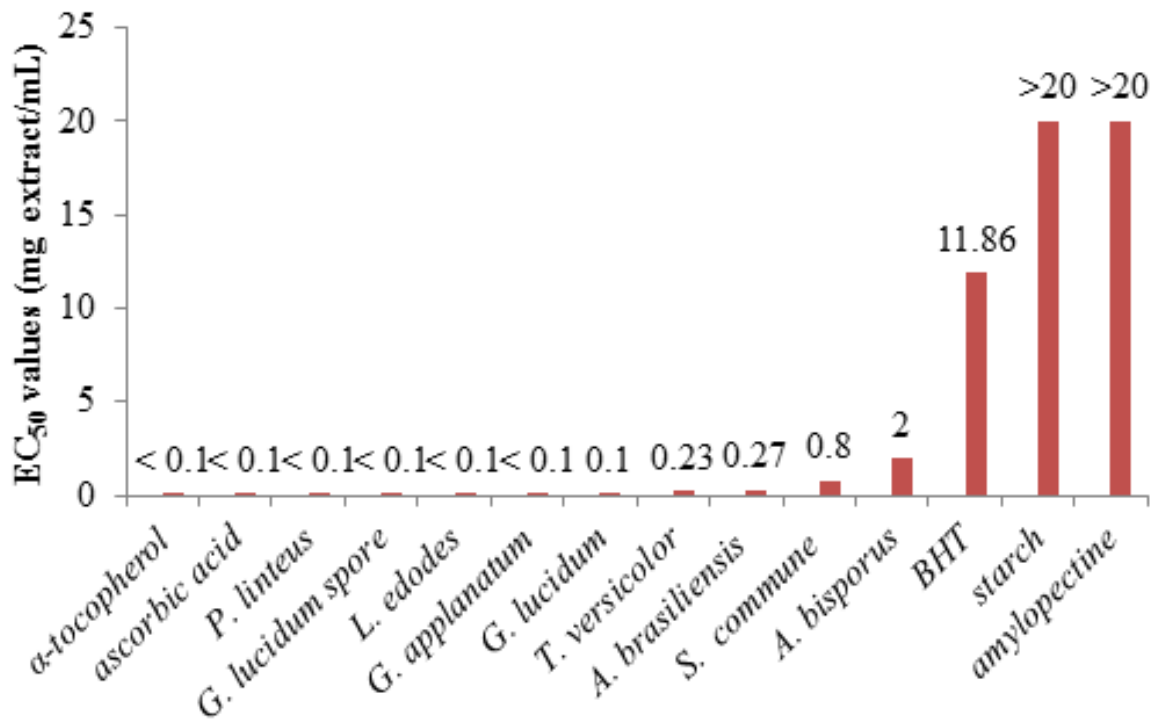

(A)

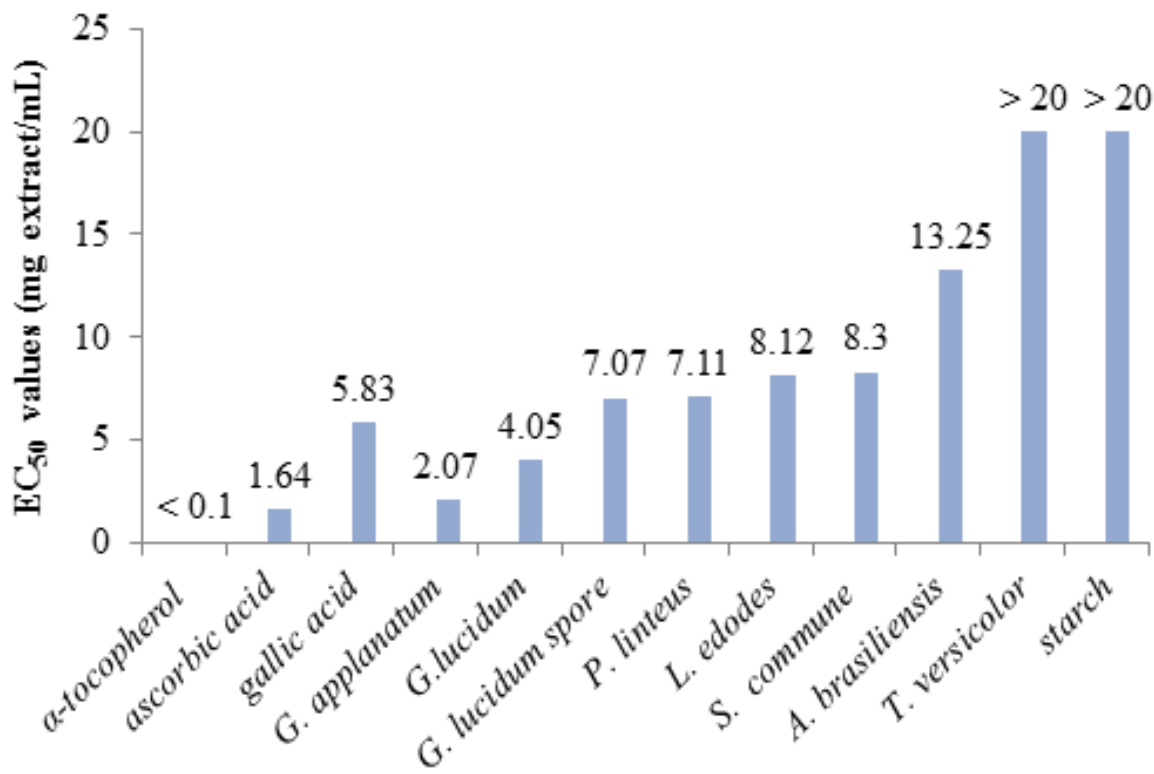

(B)

Figure 4. The antioxidant activity of the hot water polysaccharide extracts from P. linteus, A. brasiliensis, A. bisporus, S. commune fruiting bodies, G. lucidum spore and polysaccharide extracts from L. edodes, G. applanatum, G. Iucidum and T. versicolor fruiting bodies purified by dialysis (MWCO: 8.000-10.000) in scavenging ability on DPPH (A) and inhibition of lipid peroxidation evaluated in the linoleic acid model system $(B)$ expressed as $E C_{50}(\mathrm{mg} / \mathrm{mL})$ values which are the effective concentrations of each mushroom extract that are required to show $50 \%$ antioxidant properties. A lower $E C_{50}$ value corresponds to higher antioxidant activity of the mushroom's extract. Standards: ascorbic acid, $\alpha$-tocopherol, gallic acid, BHT, starch and amylopectine. 
units in polysaccharide extracts and inhibitory activity has been determined. The inhibitory activity increases with the increase of concentrations of mannose and rhamnose, and decreases with the decrease in the content of arabinose and glucose [84].

\section{Influence of phenolic compounds in polysaccharide} extracts on antioxidative properties

Polysaccharides in the fungal cell wall may be bound by covalent (ester) linkeages with proteins via remains of tyrosine and with ferulic acid that has resulted from the lignin degradation process $[94,95]$. Also, it has been detected that with aging, the structure and chemical composition of the fungal cell wall has been changed. Older cells are featured by a layered wall that has thickened in the interior, and it comprises pigments and other materials that may be found in the wall of young cells [96].

By measuring the ability to scavenge hydroxyl radicals by electron paramagnetic resonance (EPR) of polysaccharide extracts obtained by hot water extraction and dialysis (MWCO: 6000-8000) from the fruiting bodies of the fungus $G$. tsugae at various stages of maturity, as well as from the mycelium and fermentation filtrate, a lower efficacy was found as compared to non dialyzed extracts of this fungus, which indicates that the components of smaller molecular masses that are present in extracts and that have not been exposed to dialysis contribute significantly to antioxidant activity $[80,97]$.

In recent investigations of polysaccharide extracts of higher fungi, obtained in various ways (hot water or alkaline extraction, additional dialysis), the presence of phenolic compounds has been detected to various extents $[76,86,98]$. The intensity of the colour of an extract is in positive correlation with the increased content of the total phenols, meaning the larger content of phenols - the darker colour of the extract [85]. A darker colour of the extracted polysaccharide was associated with a higher antioxidant activity.

According to the structural analogy with oxidated derivatives of monophenols that occur as intermediary products in the polyphenol oxidase driven browning from damages inflicted to the tissue of plants, it seems that during extraction of polysaccharides, when fungal tissue is damaged, the phenol oxidase has access to the phenolic compounds of the extracts [99], the oxidations leading to browning then occur $[100,101]$. The polyphenol oxidases, such as tyrosinase, that were first discovered in mushrooms, are widely spread in the phylogenetic scale and catalyze the hydroxylation of monophenols and/or 0 -diphenols, that further oxidate into derivatives of $o$-quinones, which polymerize to form brown-coloured pigments generally known as melanins [102,103].
By testing the reductive ability of water and alkaline polysaccharide extracts, very high correlation between the total content of phenols and reductive ability has been observed $[76,77,86,90]$. In water polysaccharide extracts, isolated from the fungal fruiting bodies that are additionally purified by dialysis and alcohol precipitation, a very high correlation with the total content of $\alpha$-glucans has been detected, besides very high correlation with the total content of phenol [76]. With the increase of the total content of phenol and $\alpha$-glucans the reductive ability also increases, which indicates a possible creation of phenolic and $\alpha$-glucan complexes in the investigated polysaccharides of fungal extracts.

In the analysis of the FT-IR spectra of these polysaccharide extracts, the presence of typical absorption bands was detected, that corresponds to the structures that are typical for polysaccharides, as well as absorption peaks typical for protein structures, and additionally, absorption peaks that correspond to frequences typical for aromatic structures, aliphatic groups and phenols have been detected, which all indicate the presence of aromatic compounds originating from pigments [76]. The FT-IR spectrum of the polysaccharide extract of the fungus $G$. applanatum contains absorption band in the area typical for uronic acids, which reveals the presence of free or esterified $\mathrm{C}=\mathrm{O}$ groups, as structural components of one (or more) polysaccharides which may be found in the tested extract, Figure 5. G. applanatum is a lignicolus fungus, which indicates the presence of enzyme systems that participate in lignin degradation processes. cis-ferulic acid is a yellow-coloured compound that shows a FT-IR band in the $1600 \mathrm{~cm}^{-1}$ region [104] which is indicative for aromatic $\mathrm{C}=\mathrm{C}$ conjugated with $\mathrm{C}=\mathrm{O}$ and/or $\mathrm{COO}^{-}$groups [105]. During the extraction of polysaccharide extracts by hot water, the native protein structure is disturbed, but the procedure is insufficiently effective for the breaking of covalent interactions between the remains of tyrosine and polysaccharides, as well as ferulic acid and polysaccharides $[94,106]$.

By testing the antioxidative potential of the complex of oligosaccharides and ferulic acid, the greater antioxidative ability has been confirmed, as compared to free ferulic acid [107]. Even more, these complexes have exhibited a higher antioxidative potential than ascorbic acid [108]

\section{Influence of proteins in polysaccharide extracts on} antioxidative properties

The analysis of the protein content in polysaccharide fungal extracts obtained by hot water extraction, and of extracts that have been additionally exposed to dialysis and alkaline extracts, has confirmed the presence of these compounds in various quantities $[75,76,79,98]$. Even with thermal treatment full depro- 


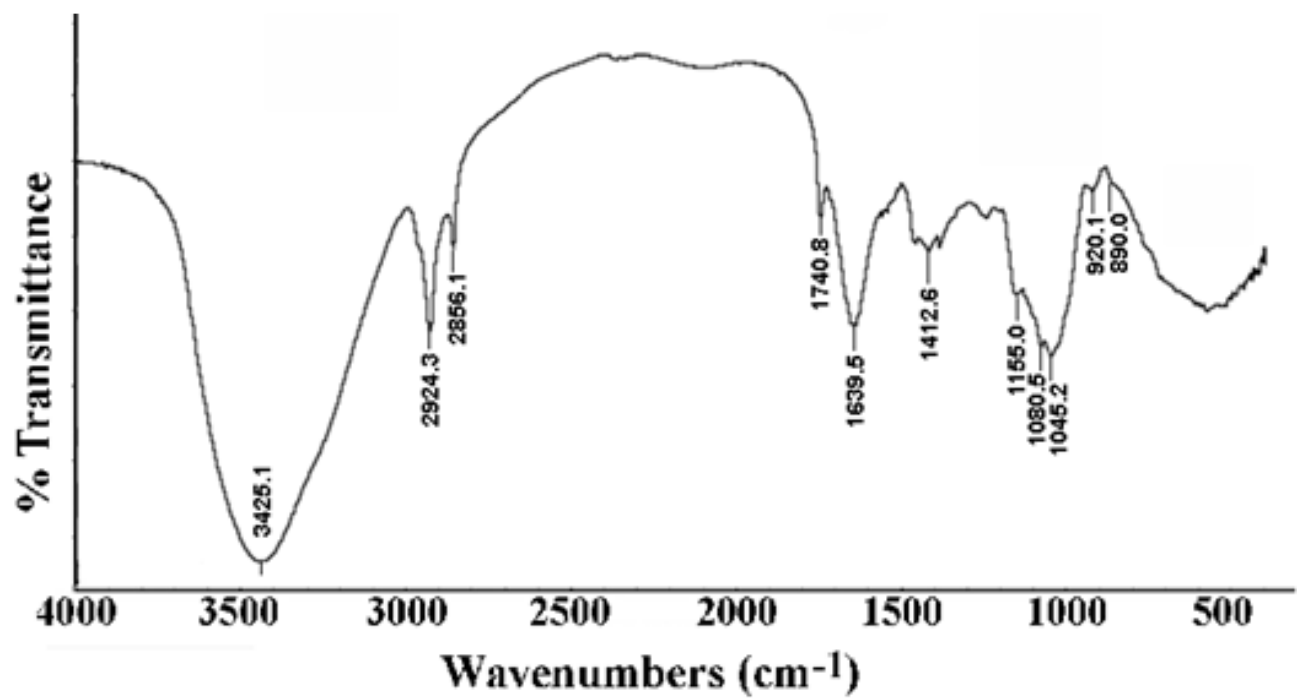

Figure 5. FT-IR Spectrum of polysaccharide extract obtained from fruiting bodies of G. applanatum [76]. (Figure reprinted with permission from Elsevier). FT-IR assignments, wave number $\left(\mathrm{cm}^{-1}\right)$ : 3000-3500 stretching vibration (str) O-H and $\mathrm{N}-\mathrm{H} ; 2920-2930$ str of asymmetric $\left(\mathrm{CH}_{2}\right) ; 2950-2850$ str of aliphatic $(\mathrm{C}-\mathrm{H}) ; 1690-1750 \mathrm{str}(\mathrm{C}=\mathrm{O})$ of free acid group and of $(\mathrm{C}=\mathrm{O})$ of ester group; 1600-1650 str of amide I, $C=O$ and $C=C$ aromatic; 1520-1410 str of amide II (CN stretching, NH bending); 1410-1400 str of aliphatic C-C chain; 1410-1310 str of OH of phenolics; 1200-900 finger prints of carbohydrates, namely 1155-1150 str of C-O-C; 1080 str of $\beta$-glucans 1020 str of C-O; 920 str of $\alpha$-glycosidic linkage; 890 str of $\beta$-glycosidic linkage.

teinisation of polysaccharide extracts cannot be achieved.

Investigations relating to the ability to scavenge superoxide and hydroxyl radicals have revealed that the quantity of proteins (peptides) that are present in polysaccharide - protein complexes has an impact on the properties [109]. Extracts of lentinan and schizophyllan, polysaccharides of Lentinula edodes and Schizophyllum commune, in which the presence of proteins has been detected in traces, have not exhibited a significant antioxidative activity. On the contrary, the polysaccharide-protein complex (PSK) that has been obtained from the mycelium of Coriolus versicolor and polysaccharide extracts of the fruiting bodies of Ganoderma lucidum and Grifola umbellata with a higher share of proteins have proven to be more effective in antioxidative activity [109].

In recent investigations of the DPPH-TEAC antioxidative activity of polysaccharide extracts of higher fungi, no correlation with protein content was detected, and only a small correlation was observed, with the occurrence of reactive oxygen species (ROS) in an in vitro culture of leukemia cells $\mathrm{K} 625$, indicating a limited or no role for protein in scavenging activity and in the generation of ROS [74].

By testing the ability to chelate $\mathrm{Fe}^{2+}$ of polysaccharide extracts of higher fungi obtained by hot water extraction, moderate correlation with the total protein content was detected, which is explained by the catalyzation of the oxyidation of $\mathrm{Fe}^{2+}$ by tyrosinases that had remained present in the protein mixture after extraction, and contributed to the chelating ability [75]. The correlation between the total content of phenols and chelating ability in all extracts was high. All polysaccharides extracts were more effective chelators of ferrous ions than citric acid whose chelating effect does not exceed $10 \%[75,90]$.

Moderate correlation was determined between the reducing ability on $\mathrm{Fe}^{3+}$ and the total protein content, which may be a consequence of the presence of reductive amino acids of cystein, methionine and tyrosine in proteins of the extract $[75,90]$.

\section{Toxic effect}

Individual substances that have proven to be good antioxidants exhibit some adverse, cytotoxic effects, depending on the tested physiological conditions and the applied dosage.

For example, epigallocatechin-3-gallate (EGCG) which is isolated from green tea leaves induces the activation of protein caspases- 3 and c-Jun N-terminal kinases (JNKs) sometimes known as stress-activated kinases (SAPKs), which belongs to the group of mitogen-activated protein kinases (MAPKs) that have a role in the process of programmed cell death, i.e. apoptosis. This effect depends on the dosage and the time of exposure, and it particularly occurs at higher concentrations. It is possible that low concentrations of EGCG activate MAPK, leading to antioxidant responsive element (ARE)-mediated gene expression, whereas higher concentrations and sustained activation of MAPKs lead to apoptosis $[50,110]$.

The expression of genes encoding antioxidative and Phase II detoxification enzymes is induced in cells exposed to electrophilic compounds and phenolic antioxidants. Induction of these enzymes is regulated at 
the transcriptional level and is mediated by a specific enhancer, ARE, found in the promoter of the enzyme's gene [111]. Involvement of the ARE in controlling constitutive gene expression implies a critical role of the enhancer in the maintenance of cellular redox homeostasis under both stressed and non-stressed conditions [111].

Some synthetic antioxidants that are largly applied as supplements to natural antioxidants may cause adverse toxic effects under certain conditions $[47,48]$. BHA, which is very often used as additive in food industry, may have negative effects on the regulation of the activity of MAPK depending on the dosage [112]. The induction of apoptosis in hepatocytes of rats in vitro, with the addition of a larger quantity of BHA is achieved through direct release of cytochrome $C$ [113].

Cytotoxic effects of polysaccharide extracts of higher fungi on primary cells have not been reported up-to-date $[114,115]$.

\section{CONCLUSION}

Investigations of antioxidative properties of polysaccharide extracts obtained from various species of higher fungi reveal their obvious antioxidative potential and the consequtive possibility for their application as the new potential antioxidants.

The antioxidative activity of extracts is exhibited even after a thermal treatment is applied in order to isolate extracts the most effectively from the cell wall of higher fungi. The antioxidative activities depend on the content of polysaccharides, phenols and proteins in polysaccharide extracts.

Immunomodulatory, anti-tumor and antioxidative properties of polysaccharide extracts of higher fungi have been shown and supported by our data indicating that they might be effectively applied as dietary supplements in everyday nutrition. Good results in the prevention of lipid peroxidation indicate the application of polysaccharide extracts of higher fungi as functional additives in the preservation of the stability of foodstuffs [116,117].

$\beta$-Glucans are applied in cosmetology as protective creams that prevent irritation and diseases of the skin, also stimulating the skin cell proliferation and collagen biosynthesis $[22,118,119]$. Polysaccharide extracts of fungi with antioxidative properties have commercial application in creams that provide protection from ultraviolet rays and from other detrimental effects caused by activities of free radicals that lead to damages and aging of the skin.

Investigations of factors that have influence upon the antioxidative properties of polysaccharide extracts are in the progress. The investigations are focused on the antioxidative mechanisms of action and further studies on the complexity of structural interactions between polysaccharide, phenols and protein components of the extracts.

Very high correlations between the total content of phenols in polysaccharide extracts of higher fungi have been detected in the investigations related to the reducing ability and chelating ability of $\mathrm{Fe}^{2+}[90]$. The quantification of total phenols using Folin-Ciocalteu reagent is based on electron transfer reactions [120]. Therefore, when one determines phenolic compounds, one has to take into account the presence of other compounds in the extracts, such as organic acids, sugars and amino acids that may also take part in the electron transfer processes. Even if one puts aside the presence of these compounds, the various phenolic compounds give various results with the Folin-Ciocalteu reagent. While catechin, rutin, caffeic acid and gallic acid behave in a similar way, some flavonoids exhibit less absorption than expected, which leads to a wrongful interpretation of results. Therefore, it is necessary to identify precisely the nature, as well as the structure of phenolic compounds responsible for the antioxidant activity of polysaccharide extracts of higher fungi.

\section{Acknowledgements}

This paper is a result of Projects III 46001, III 46010 and III 43004 financed by the Ministry of Education, Science and Technological Development of the Republic of Serbia and the EU Commission project AREA, No 316004.

\section{REFERENCES}

[1] C. Hobbs, Medicinal mushrooms, Botanica press, Empire Grade, Santa Cruz, CA, 1995.

[2] S.C. Jong, J.M. Birmingham, Medicinal benefits of the mushroom Ganoderma, Adv. Appl. Microbiol. 37 (1991) 101-134.

[3] T. Mizuno, Bioactive biomolecules of mushrooms: food function and medicinal effect of mushroom fungi, Food Rev. Int. 11 (1995) 7-21.

[4] S.P. Wasser, A.L. Weis, Therapeutic effects of substances occurring in higher Basidiomycetes mushrooms: a modern perspective, Crit. Rev. Immunol. 19 (1999) 65-96.

[5] T. Mizuno, The extraction and development of antiitumour-active polysaccharides from medicinal mushrooms in Japan, Int. J. Med. Mushrooms 1 (1999) 9-29.

[6] B.Z. Zaidman, M. Yassin, J. Mahajna, S.P. Wasser, Medicinal mushroom modulators of molecular targets as cancer therapeutics, Appl. Microbiol. Biotechnol. 67 (2005) 453-468.

[7] K. Oba, S. Termukai, M. Kobayashi, T. Matsui, M. Kodera, J. Skamoto, Efficacy of adjuvant immunochemotherapy with polysaccharide $\mathrm{K}$ for patients with curative resections of gastric cancer, Cancer Immunol. Immunother. 56 (2007) 905-911. 
[8] N. Ohno, M. Furukawa, N.N. Miura, Y. Adachi, M. Motoi, T. Yadomae, Antitumor $\beta$-glucan from the cultured fruit body of Agaricus blazei, Biol. Pharm. Bull. 24 (2001) 820-828.

[9] K. Abascal, E. Yarnell, A Turkey tail polysaccharide as an immunochemotherapy agent in cancer, Altern. Compl. Ther. 13 (2007) 178-182.

[10] J. Jiang, V. Slivova, K. Harvey, T. Valachovicova, D. Sliva, Ganoderma lucidum suppresses growth of breast cancer cells through the inhibition of Akt/NF- $k B$ signaling, Nutr. Cancer 49 (2004) 209-216.

[11] G.D. Brown, S. Gordon, Immune recognition. A new receptor for beta-glucans, Nature 413 (2001) 36-37.

[12] A. Mueller, J. Raptis, P. J. Rice, H. Kalbfleisch, D. Stout, H. E. Ensley, W. Browder, D. L. Williams, The influence of glucan polymer structure and solution conformation on binding to (1-3)-beta-D-glucan receptors in human monocyte-like cell line, Glycobiology 10 (2000) 339-346.

[13] J. Herre, S. Gordon, G.D. Brown, Dectin-1 and its role in the recognition of $\beta$-glucans by macrophages, Mol. Immunol. 40 (2004) 869-876.

[14] B.M. Shao, H. Dai, W. Xu, Z.B. Lin, X.M. Gao, Immune receptors for polysaccharides from Ganoderma lucidum, Biochem. Biophys. Res. Commun. 323 (2004) 133-141.

[15] Ch. Lull, H. J. Wichers, H. F. J. Savelkoul, Antiiflammatory and immunomodulating properties of fungal metabolites, Mediators Inflamm. 2 (2005) 63-80.

[16] J.P. Angeli, L.R. Ribeiro, M.L. Gonzaga, A. Soares Sde, M.P. Ricardo, M.S. Tsuboy, R. Stidl, S. Knasmueller, R.E. Linhares, M.S. Mantovani, Protective effects of betaglucan extracted from Agaricus brasiliensis against chemically induced DNA damage in human lymphocytes, Cell. Biol. Toxicol. 22 (2006) 285-291.

[17] G. Pillail Thulasi, C.K.K. Nair, K.K. Janardhanan, Enhancement of repair of radiation induced DNA strand breaks in human cells by Ganoderma mushroom polysaccharides, Food Chem. 199 (2010) 1040-1043.

[18] N. Kubo, Y. Myojin, F. Shimamoto, N. Kashimoto, E. Kyo, K. Kamiya, H. Watanabe, Protective effects of a watersoluble extract from cultured medium of Ganoderma lucidum (Rei-shi) mycelia and Agaricus blazei murill against $X$-irradiation in B6C3F1 mice: Increased small intestinal crypt survival and prolongation of average time to animal death, Int. J. Mol. Med. 15 (2005) 401$-406$.

[19] S.C. Jong, R. Donovick, Antitumor and antiviral substances from fungi, Adv. Appl. Microbiol. 34 (1990) 183-262 .

[20] S. Sarkar, Antiviral effect of the extract of culture medium of Lentinus edodes on the replication of the herpes simplex virus type 1, Antivir. Res. 20 (1993) 293-303 .

[21] H. Nanba, N. Kodama, D. Schar, D. Turner, Effects of Maitake (Grifola frondosa) glucan in HIV-infected patients, Mycoscience 41 (2000) 293-295.

[22] C. Laroche, P. Michaud, New developments and prospective applications for $\beta(1,3)$ glucans, Recent Pat. Biotechnol. 1 (2007) 59-73.
[23] S.P. Wasser, E. Nevo, D. Sokolov, S. Reshetnikov, M. Timor-Tismenetsky, Dietary supplements from medicinal mushrooms: diversity of types and variety of regulations, Int. J. Med. Mushrooms 2 (2000) 1-19.

[24] S.P. Wasser, Medicinal mushrooms as a source of antitumor and immunomodulating polysaccharides, Appl. Microbiol. Biotechnol. 60 (2002) 258-274.

[25] T. Sasaki, N. Takasuka, Further study of the structure of lentinan, an antitumour polysaccharide from Lentinus edodes, Carbohyd. Res. 47 (1976) 99-104.

[26] Y. Zhang, X. Xu, L. Zhang, Gel formation and lowtemperature intramolecular conformation transition of a triple-helical polysaccharide Lentinan in water, Biopolymers 89 (2008) 852-861.

[27] Wikipedia, The Fee Encyclopedia, April 2010 (http:// //en.wikipedia.org/wiki/File:Lentinan.svg).

[28] T.L. Blum, A. Sarco, The triple helical structure of lentinan, a $\beta$-(1-3)-D-glucan, Can. J. Chem. 55 (1977) 293$-299$.

[29] J.A. Bohn, J.N. Be Miller, (1-3)- $\beta$-D-glucans as biological response modifiers: a review of structure-functional activity relationships, Carbohyd. Polym. 28 (1995) 3-14.

[30] A.H. Bae, S.W. Lee, M. Ikeda, M. Sano, S. Shinkai, K. Sakurai, Rod-like architecture and helicity of the poly(C)/schizophyllan complex observed by AFM and SEM, Carbohyd. Res. 339 (2004) 251-258.

[31] F.R. Smiderle, A.C. Ruthers, J. van Arkel, W. Chanput, M. lacomini, H.J. Wichers, L.J.L.D. van Griensven, Polysaccharides from Agaricus bisporus and Agaricus brasiliensis show similarities in their structures and their immunomodulatory effects on human monocytic THP-1 cells, BMC Complementary and Alternative Medicin 11: 58, 2011 (http://www.biomedcentral.com/1472$-6882 / 11 / 58)$.

[32] E.R. Carbonero, A.C. Ruthers, C.S. Freitas, P. Utrilla, J. Galvez, E.V. da Silva, G.L. Sassaki, P.A.J. Gorin, M. lacomini, Chemical and biological properties of a highly branched $\beta$-glucan from edible mushroom Pleurotus sajor-caju, Carbohyd. Polym. 90 (2012) 814-819.

[33] S.P. Wasser, Medicinal mushroom science: history, current status, future trends, and unsolved problems, Int. J. Med. Mushrooms 12 (2010) 1-16.

[34] A.T. Yap, M.L.M. Ng, An improved method for the isolation of lentinan from edible and medicinal shiitake mushroom, Lentinus edodes (Berk.) Sing. (Agaricomycetideae), Int. J. Med. Mushrooms 3 (2001) 6-19.

[35] D.B. Zekovic, S. Kwiatkowski, M.M. Vrvic, D.M. Jakovljevic, C.A. Moran, Natural and modified $(1 \rightarrow 3)$ beta-D-glucans in health promotion and disease alleviation (Review), Crit. Rev. Biotechnol. 25 (2005) 205-230 .

[36] M. Ghoneum, M. Wimbley, F. salem, A. McKlain, N. Attallah, G. Gill, Immunomodulatory and anticancer effects of active hemicellulose compound (AHCC), Int. J. Immunother. 11 (1995) 23-28.

[37] K. Matsushita, Y. Kuramitsu, Y. Ohiro, M. Obara, M. Kobayashi, Y.Q. Li, M. Hosokawa, Combination therapy of active hexose correlated compound plus UFT signi- 
ficantly reduces the metastasis of of rat mammary adenocarcinoma, Anti. Cancer Drugs 9 (1998) 343-350.

[38] B. Sun, K. Wakame, E. Sato, H. Nishioka, O. I. Aruoma, H. Fujii, The effect of active hexose correlated compound in modulating cytosine arabinoside-induced hair loss, and 6-mercaptopurine- and methotrexate-induced liver injury in rodents, Cancer Epidemiol. 33 (2009) 293-299.

[39] B. Halliwell, J.M.C. Gutteridge, Role of free radicals and catalytic metal ions in human disease: an overview, Methods Enzymol. 186 (1990) 1-85.

[40] B.N. Ames, M.K. Shigenaga, T.M. Hagen, Oxidants, antioxidants, and the degenerative diseases of aging, Proc. Nat. Acad. Sci. USA 90 (1993) 7915-7922.

[41] A.M. Papas, Antioxidant status, diet, nutrition and health, CRC Press, Boca Raton, FL, 1999.

[42] M.J. Morgan, Z.G. Liu, Review: Crosstalk of reactive oxygen species and NF-KB signaling, Cell Res. 21 (2011) 103-115.

[43] W. Droge, Free radicals in the physiological control of cell function, Physiol. Rev. 82 (2002) 47-95.

[44] E. Ho, T.M. Bray, Antioxidants, NFkappaB activation, and diabetogenesis, Proc. Soc. Exp. Biol. Med. 222 (1999) 205-213.

[45] A. Siomek, Review: NF-KB signaling pathway and free radical impact, Acta Biochim. Polon. 59 (2012) 323-331.

[46] M. Laguerre, J. Lecomte, P. Villeneuve, Evaluation of the ability of antioxidants to counteract lipid oxidation: Existing methods, new trends and challenges, Prog. Lipid Res. 46 (2007) 244-282.

[47] H.C. Grice, Safety evaluation of butylated hydroxyanisole from the perspective of effects on forestomach and oesophageal squamous epithelium, Food Chem. Toxicol. 26 (1988) 717-723.

[48] R. Kahl, H. Kappus, Toxicology of the synthetic antioxidants BHA and BHT in comparison with the natural antioxidant vitamin E, Z. Lebensm. Unters. Forsch. 196 (1993) 329-338.

[49] A.K. Tiwari, Antioxidant: New generation therapeutic base for treatment of polygenic disorders, Curr. Sci. 86 (2004) 1092-1102.

[50] J.W. Finley, A. N. Kong, K. J. Hintze, E. H. Jeffery, L. L. Ji, $X$. G. Lei, Antioxidants in foods: state of the science important to the food industry, J. Agric. Food Chem. 59 (2011) 6837-6846.

[51] European Food Safety Authority; Outcome of a public consultation on the Draft Opinion of the EFSA Panel on Dietetic Products, Nutrition, and Allergies (NDA) on a guidance on the scientific requirements for health claims related to gut and immune function. Supporting Publications 2011:208 [84 pp.]. Available online: www.efsa.europa.eu

[52] A. Moure, J.M. Cruz, D. Franco, J.M. Domoanguez, J. Sineiro, H. Domoanguez, M.J. Nuanaez, J.C. Parajoa, Review: Natural antioxidants from residual sources, Food Chem. 72 (2001) 145-171.

[53] A. Prakash, F. Rigelhof, E. Miller, in: J. De Vries (Ed.), Medallion Laboratories Analytical Progress: Antioxidant Activity, Medallion Laboratories, Minneapolis, MN, 2001, pp. 1-6.
[54] J. Tabart, C. Kevers, J. Pincemail, J.O. Defraigne, J. Dommes, Comparative antioxidant capacities of phenolic compounds measured by various tests, Food Chem. 113 (2009) 1226-1233.

[55] V.V. Kedage, J.C. Tilak, G.B. Dixit, T.P.A. Devasagayam, M. Mhatre, A study of antioxidant properties of some varieties of grapes (Vitis vinifera L.), Crit. Rev. Food Sci. 47 (2007) 175-185.

[56] M.N. Maillard, C. Berset, Evolution of antioxidant activity during kilning, role of insoluble bound phenolic acids of barley and malt, J. Agric. Food Chem. 43 (1995) 1789-1793.

[57] M.N. Maillard, M.H. Soum, P. Boivin, C. Berset, Antioxidant activity of barley and malt, relationship with phenolic content, LWT-Food Sci. Technol. 29 (1996) 238-244.

[58] A. Bocco, M.E. Cuvelier, H. Richard, C. Berset, Antioxidant activity and phenolic composition of citrus peel and seed extracts, J. Agric. Food Chem. 46 (1998) 2123 -2129 .

[59] R.L. Prior, X. Wu, K. Schaich, Standardized methods for the determination of antioxidant capacity and phenolics in foods and dietary supplements, J. Agric. Food Chem. 53 (2005) 4290-4302.

[60] A.V. Badarinath, K. Mallikarjuna Rao, C. Madhusudhana Chetty, S. Ramkanth, T.V.S. Rajan, K. Gnanaprakash, A review on in vitro antioxidant methods: comparisions, correlations and considerations, Int. J. PharmTech Res. 2 (2010) 1276-1285.

[61] M.H. Gordon, The mechanism of antioxidant action in vitro, in: B.J.F. Hudson (Ed), Food antioxidants, Elsevier, Amsterdam, 1990, pp. 1-18.

[62] M. Johnson, G. Loo, Effects of epigallocatechin gallate and quercetin on oxidative damage to cellular DNA, Mutat. Res. 459 (2000) 211-218.

[63] G. Yen, P.D. Ch Duh, H.L. Tsai, Antioxidant and prooxidant properties of ascorbic acid and gallic acid, Food Chem. 79 (2002) 307-313.

[64] G. Cao, E. Sofic, R.L. Prior, Antioxidant and prooxidant behaviour of flavonoids: structure-activity relationships, Free Radic. Biol. Med. 22 (1997)749-760.

[65] K. Jorgensen, L.H. Skibsted, Carotenoid scavenging of radicals. Effect of carotenoid structure and oxygen partial pressure on antioxidative activity, Z. Lebensm. Unters. Forsch. 196 (1993) 423-429.

[66] E.N. Frankel, S.W. Huang, J. Kanner, J.B. German, Interfacial phenomena in the evaluation of antioxidants: bulk oils vs. emulsions, J. Agric. Food Chem. 42 (1994) 1054-1059.

[67] P. Pedrielli, G.F. Pedulli, L.H. Skibsted, Antioxidant mechanism of flavonoids. Solvent effect on rate constant for chain-breaking reaction of quercetin and epicatechin in autoxidation of methyl linoleate, J. Agric. Food Chem. 49 (2001) 3034-3040.

[68] W. Porter, E.D. Black, A.M. Drolet, Use of polyamide oxidative fluorescence test on lipid emulsions: contrast in relative effectiveness of antioxidants in bulk versus dispersed systems, J. Agric. Food Chem. 37 (1989) 615$-624$. 
[69] H. Fu, D. Shieh, C. Ho, Antioxidant and free radical scavenging activities of edible mushrooms, J. Food Lipids 9 (2002) 35-46.

[70] M. Elmastas, O. Isildak, I. Turkekul, N. Temur, Determination of antioxidant activity and antioxidant compounds in wild edible mushrooms, J. Food Comp. Anal. 20 (2007) 337-345.

[71] L.M. Cheung, P.C.K. Cheung, V.E.C. Ooi, Antioxidant activity and total phenolics of edible mushroom extracts, Food Chem. 81 (2003) 249-255.

[72] H.N.D. Bao, K. Osako, T. Ohshima, Value-added use of mushroom ergothioneine as a colour stabilizer in processed fish meats, J. Sci. Food Agric. 90 (2010) 1634-1641 .

[73] N.G. Puttaraju, S.U. Venkateshaiah, S.M. Dharmesh, S.M.N. Urs, R. Somasundaram, Antioxidant activity of indigenous edible mushrooms, J. Agric. Food Chem. 54 (2006) 9764-9772.

[74] W. Song, L.J.L.D. Van Griensven, Pro- and antioxidative properties of medicinal mushroom extracts, Int. J. Med. Mushrooms 10 (2008) 315-324.

[75] M. Kozarski, A. Klaus, M. Niksic, D. Jakovljevic, P.F.G.J. Helsper, L.J.L.D. Van Griensven, Antioxidative and immunomodulating activities of polysaccharide extracts of the medicinal mushrooms Agaricus bisporus, Agaricus brasiliensis, Ganoderma lucidum and Phelinus linteus, Food Chem. 129 (2011) 1667-1675.

[76] M. Kozarski, A. Klaus, M. Niksic, M.M. Vrvic, N. Todorovic, D. Jakovljevic, L.J.L.D. Van Griensven, Antioxidative activities and chemical characterization of polysaccharide extracts from the widely used mushrooms Ganoderma applanatum, Ganoderma lucidum, Lentinus edodes and Trametes versicolor, J. Food Comp. Anal. 26 (2012) 144-153.

[77] S.A. Heleno, L. Barrosc, A. Martins, M.J.R.P. Queiroz, C. Santos-Buelga, I.C.F.R. Ferreira, Fruiting body, spores and in vitro produced mycelium of Ganoderma lucidum from Northeast Portugal: A comparative study of the antioxidant potential of phenolic and polysaccharidic extracts, Food Res. Int. 46 (2012) 135-140.

[78] H.Y. Chang, Y.L. Ho, M.J. Sheu, Y.H. Lin, M.C. Tseng, S.H Wu, G.J. Huang, Y.S. Chang, Antioxidant and free radical scavenging activities of Phellinus merrillii extracts, Bot. Stud. 48 (2007) 407-417.

[79] Y. Chen, M.Y. Xie, S.P. Nie, C. Li, Y.X. Wang, Purification, composition analysis and antioxidant activity of a polysaccharide from the fruiting bodies of Ganoderma atrum, Food Chem. 107 (2008) 231-241.

[80] Y.H. Tseng, J.H. Yang, J.L. Mau, Antioxidant properties of polysaccharides from Ganoderma tsugae, Food Chem. 107 (2008) 732-738.

[81] C.Y. Guo, S.Z. Ji, C.X. Ping, Modulatory effect of Ganoderma lucidum polysaccharides on serum antioxidant enzymes activities in ovarian cancer rats, Carbohyd. Polym. 78 (2009) 258-262.

[82] C.X. Ping, C. Yan, L.S. Bing, C.Y. Guo, L.J. Yun, L.L. Ping, Free radical scavenging of Ganoderma lucidum polysaccharides and its effect on antioxidant enzymes and immunity activities in cervical carcinoma rats, Carbohyd. Polym. 77 (2009) 389-393.

[83] W. Liu, H. Wang, X. Pang, W. Yao, X. Gao, Characterization and antioxidant activity of two low-molecularweight polysaccharides purified from the fruiting bodies of Ganoderma lucidum, Int. J. Biol. Macromol. 46 (2010) 451-457.

[84] T.C.T. Lo, C.A. Chang, K.H. Chiuc, P.K. Tsayd, J.F. Jena, Correlation evaluation of antioxidant properties on the monosaccharide components and glycosyl linkages of polysaccharide with different measuring methods, Carbohyd. Polym. 86 (2011) 320-327.

[85] J. Jia, X. Zhang, Y.S. Hu, Y. Wu, Q.Z. Wang, N.N. Li, Q.C. Guo, X.C. Dong, Evaluation of in vivo antioxidant activities of Ganoderma lucidum polysaccharides in STZdiabetic rats, Food Chem. 115 (2009) 32-36.

[86] A. Klaus, M. Kozarski, M. Niksic, D. Jakovljevic, N. Todorovic, L.J.L.D. Van Griensven, Antioxidative activities and chemical characterization of polysaccharides extracted from the basidiomycete Schizophyllum commune, LWTFood Sci. Technol. 44 (2011) 2005-2011.

[87] S.C. Jong, J.M. Birmingham, Medicinal benefits of the mushroom Ganoderma, Adv. Appl. Microbiol. 37 (1992) 101-134.

[88] K. Minato, M. Mizuno, H. Ashida, T. Hashimoto, H. Terai, $\mathrm{H}$. Tsuchida, Influence of storage conditions on immunomodulating activities of Lentinus edodes, Int. J. Med. Mushrooms 1 (1999) 243-250.

[89] K. Minato, M. Mizuno, S. Kawakami, S. Tatsuoka, Y. Denpo, K. Tokimato, H. Tsuchida, Changes in immunemodulating activities and content of antitumour polysaccharides during growth of two mushrooms, Lentinus edodes (Berk.) Sing and Grifola frondosa (Dicks:Fr.) S.F. Gray, Int. J. Med. Mushrooms 3 (2001) 1-7.

[90] M. Kozarski, Chemical characterization, antioxidative and antimicrobial properties of polysaccharide extracts from the selected mushroom species, PhD Thesis, Faculty of Chemistry, University of Belgrade, 2012.

[91] E. Tsiapali, S. Whaley, J. Kalbfleisch, H.E. Ensley, I.W. Browder, D.L. Williams, Glucans exhibit weak antioxidant activity, but stimulate macrophage free radical activity, Free Radical Bio. Med. 30 (2001) 393-402.

[92] O.B. Laugier, S.D. Spasić, V. Mandić, D. Jakovljević, M. M. Vrvić, The effects of repetitive alkaline/acid extractions of Saccharomyces cerevisiae cell wall on antioxidative and bifidogenic efficacy, Int. J. Food Sci. Tech. 47 (2012) 369-375.

[93] I.I. Koleva, T.A. van Beek, J.P.H. Linssen, A. de Groot, L.N. Evstatieva, Screening of plant extracts for antioxidant activity: a comparative study on three testing methods Phytochem. Anal. 13 (2002) 8-17.

[94] S.C. Fry, Oxidative coupling of tyrosine and ferulic acid residues: Intra- and extra-protoplasmic occurrence, predominance of trimers and larger products, and possible role in inter-polymeric cross-linking, Phytochem. Rev. 3 (2004) 97-111.

[95] D.W.S. Wong, Feruloyl esterase: a key enzyme in biomass degradation, Appl. Biochem. Biotechnol. 133 (2006) 87-112. 
[96] J. Deacon, Fungal Biology, $4^{\text {th }}$ ed., Blackell Publishing Limited, Oxford, 2006.

[97] J.L. Mau, S.Y. Tsai, Y.H. Tseng, S.J. Huang, Antioxidant properties of hot water extracts from Ganoderma tsugae Murrill, LWT-Food Sci. Technol. 38 (2005) 589-597.

[98] C. Thetsrimuang, S. Khammuang, K. Chiablaem, C. Srisomsap, R. Sarnthima, Antioxidant properties and cytotoxicity of crude polysaccharides from Lentinus polychrous Lév, Food Chem. 128 (2011) 634-639.

[99] R. Russell, M. Paterson, Review: Ganoderma-A therapeutic fungal biofactory, Phytochemistry 67 (2006) 1985-2001.

[100] L.G. Fenoll, J.N. Rodriguez-Lopez, R. Varon, P.A. GarciaRuiz, F. Garcia-Canovas, J. Tudela, Action mechanism of tyrosinase on meta- and para-hydroxylated monophenols, J. Biol. Chem. 381 (2000) 313-320.

[101] L.G. Fenoll, J.N. Rodriguez-Lopez, F. Garcia-Sevilla, J. Tudela, P.A. Garcia-Ruiz, R. Varon, F. Garcia-Canovas, Oxidation by mushroom tyrosinase of monophenols generating slightly unstable o-quinones, Eur. J. Biochem. 267 (2000) 5865-5878.

[102] G. Prota, in: H. B. Jovanovich (Ed.), Melanins and Melanogenesis: Tyrosinase, Academic Press, San Diego, CA, 1992, pp. 34-62.

[103]C.W.G. Van Gelder, W.A.A.W.H.J. Flurkey, Sequence and structural features of plant and fungal tyrosinases, Phytochemistry 45 (1997) 1309-1323.

[104] U.P. Agarwal, R.H. Atalla, Formation and identification of cis/trans ferulic acid in photoyellowed white spruce mechanical pulp, J. Wood Chem. Technol. 10 (1990) 169-190.

[105]P. McCarthy, J. A. Rice, in: G.R. Aiken, G.R. McKnight, R.L. Wershaw, P.P. McCarthy (Eds.), Humic Substances In Soil, Sediment, And Water: Spectroscopic Methods (other than NMR) For Determining Functionality In Humic Substances, Wiley-Interscience, New York, 1985, pp. $527-560$.

[106]S.C. Fry, Phenolic components of the primary cell wall. Feruloylated disaccharides of D-galactose and L-arabinose from spinach polysaccharide, Biochemistry 203 (1982) 4493-44504.

[107]X.P. Yuan, J. Wang, H.Y. Yao, F. Chen, Free radical scavenging capacity and inhibitory activity on rat erythrocyte hemolysis of feruloyl oligosaccharides from wheat bran insoluble dietary fiber, LWT - Food Sci. Technol. 38 (2005) 877-883.

[108]S.Y. Ou, G.M. Jackson, X. Jiao, J. Chen, J.Z. Wu, X.S. Huang, Protection against oxidative stress in diabetic rats by wheat bran feruloyl oligosaccharides, J. Agric. Food Chem. 55 (2007) 3191-3195.
[109]F. Liu, V.E.C. Ooi, S.T. Chang, Free radical scavenging activities of polysaccharide extracts, Life Sci. 60 (1997) 763-761.

[110]C. Chen, R. Yu, E.D. Owuor, A.N.T. Kong, Activation of antioxidant-response element (ARE), mitogen-activated protein kinases (MAPKs) and caspases by major green tea polyphenol components during cell survival and death, Arch. Pharm. Res. 23 (2000) 605-612.

[111]T. Nguyen, P.J. Sherratt, C.B. Pickett, Regulatory mechanisms controlling gene expression mediated by the antioxidant response element, Pharmacol. Toxicol. 43 (2003) 233-260.

[112] R. Yu, T.H. Tan, A.N. Kong, Butylated hydroxyanisole and its metabolite tert-butylhydroquinone differentially regulate mitogen-activated protein kinases. The role of oxidative stress in the activation of mitogen-activated protein kinases by phenolic antioxidants, J. Biol. Chem. 272 (1997) 28962-28970.

[113]R. Yu, S. Mandlekar, A.N. Kong, Molecular mechanisms of butylated hydroxylanisole-induced toxicity: induction of apoptosis through direct release of cytochrome c, Mol. Pharmacol. 58 (2000) 431-437.

[114]X. Li, Z. Wang, L. Wang, E. Walid, H. Zhang, In vitro antioxidant and anti-proliferation activities of polysaccharides from various extracts of different mushrooms, Int. J. Mol. Sci. 13 (2012) 5801-5817.

[115] J. Turło, B. Gutkowska, M. Klimaszewska, C. Kapusta, K. Schneider, M. Sikora, M. Cieślak, J. Kazmierczak-Baranska, A. Gớrski, S. Purchla, A. Gołaś, Selenium-enriched polysaccharide fraction isolated from mycelial culture of Lentinula edodes (Berk.) - preliminary analysis of the structure and biological activity, in Proceedings of the $7^{\text {th }}$ International Conference on Mushroom Biology and Mushroom Products (ICMBMP7), Arcachon, France, 2011, pp. 242-246.

[116] L. Fan, S. Zhang, L. Yu, L. Ma, Evaluation of antioxidant property and quality of breads containing Auricularia auricula polysaccharide flour, Food Chem. 101 (2007) 1158-1163.

[117]Y.F.M. Kishk, H.M.A. Al-Sayed, Free-radical scavenging and antioxidative activities of some polysaccharides in emulsions, LWT - Food Sci. Technol. 40 (2007) 270-277.

[118] M.S. Kim, K.M. Park, I.S. Chang, H.H. Kang, Y.C. Sim, $\beta$-1,6-branched $\beta$-1,3-glucans in skin care, Allured's Cosmetic Toiletries Magazine 115 (2000) 79-86.

[119]J.S. Kim, M.S. Kim, D.C. Lee, S.G. Lee, S. So, Y.T. Kim, B.H. Park, K.M. Park, Production of $\beta-1,6$-branched $\beta-1,3-$ -glucan useful as skin anti-aging, depigmenting and healing agent, 1999, JP 11313667.

[120]D. Huang, B. Ou, R.L. Prior, The chemistry behind antioxidant capacity assays, J. Agric. Food Chem. 53 (2005) 1841-1856. 


\section{IZVOD}

\section{POLISAHARIDI VIŠIH GLIVA: BIOLOŠKA ULOGA, STRUKTURA I ANTIOKSIDATIVNA AKTIVNOST}

Maja S. Kozarski ${ }^{1}$, Anita S. Klaus ${ }^{1}$, Miomir P. Nikšić ${ }^{1}$, Leo J.L.D. Van Griensven ${ }^{2}$, Miroslav M. Vrvićc ${ }^{3,4}$, Dragica M. Jakovljević ${ }^{4}$

${ }^{1}$ Univerzitet u Beogradu, Poljoprivredni fakultet, Beograd, Srbija

${ }^{2}$ Plant Research International, Wageningen University and Research Centre, Wageningen, The Netherlands

${ }^{3}$ Univerzitet u Beogradu, Hemijski fakultet, Beograd, Srbija

${ }^{4}$ Univerzitet u Beogradu, Institut za hemiju, tehnologiju i metalurgiju, Centar za hemiju, Beograd, Srbija

(Pregledni rad)

Polisaharidi gljiva privlače veliku pažnju zbog svojih interesantnih bioloških svojstava kao što su: antitumorno, antivirusno, antikomplementarno, antikoagulaciono, hipolipidemijsko dejstvo, kao i imunomodulatorska i imunostimulativna aktivnost, što ih sve čini pogodnim za primenu u mnogim oblastima, među kojima su i prehrambena industrija, kozmetika, biomedicina, poljoprivreda, zaštita životne sredine i otpadnih voda. Oksidativna oštećenja prirodnih i industrijski pripremljenih namirnica predstavljaju veliki ekonomski problem na globalnom nivou, s obzirom da direktno utiču na promenu organoleptičkih osobina proizvoda, pri čemu dolazi i do stvaranja potencijalno toksičnih jedinjenja. Zbog toga se danas sve veća pažnja posvećuje istraživanjima novih prirodnih izvora antioksidanasa, među kojima su veoma značajni i polisaharidni ekstrakti različitih bazidiomiceta. U ovom radu su prikazana biološka svojstva, struktura, kao i postupci izolovanja aktivacije polisaharida viših gljiva. Dat je i pregled antioksidativne aktivnosti polisaharidnih ekstrakata viših gljiva i razmatran je uticaj strukturnih karakteristika ovih ekstrakata na antioksidativna svojstva.
Ključne reči: Polisaharidi • Gljive • Polisaharidni ekstrakti • Antioksidativna svojstva 